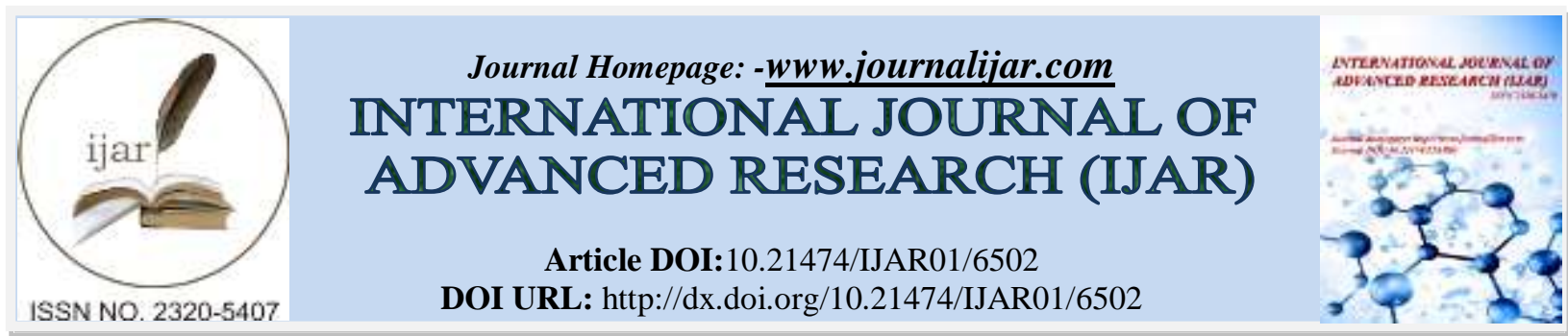

RESEARCH ARTICLE

\title{
PHYSICAL AND CHEMICAL ANALYSIS OF GROUND WATER OF TONK CITY, RAJASTHAN, INDIA.
}

\section{Shyam Soni ${ }^{1}$ and Ravindera Kumar Singh ${ }^{2}$.}

1. Bhagwant university Ajmer, Rajasthan, India.

2. Govt . P.G. College Shahpura, Bhilwara, Rajasthan ,India.

\section{Manuscript Info}

\section{Manuscript History}

Received: 11 December 2017

Final Accepted: 13 January 2018

Published: February 2018

\section{Keywords:-}

Ground water quality, Drinking water,

Fluoride, Iron, Nitrate.

\section{Abstract}

Five water samples were collected from tap and hand pump of various area of tonk city. The physical chemical parameters such as fluoride, iron, calcium, magnesium, sulphate and nitrate were analyzed in the water samples, to characterize the ground water quality and suitability for drinking purpose. All the water samples were compared with Indian standard of drinking water prescribed by bureau of Indian standard BIS 10500:2012. The physical chemical analysis of water samples of Tonk city showed that Fluoride varied from 0.0 to $0.3 \mathrm{mg} / \mathrm{l}$, Iron from 0.1 to $22.22 \mathrm{mg} / \mathrm{l}$, Calcium from 45.29 to $252.50 \mathrm{mg} / \mathrm{l}$, magnesium from 6.65 to $37.84 \mathrm{mg} / \mathrm{l}$, Sulphate from 25.74 to $94.65 \mathrm{mg} / \mathrm{l}$ and Nitrate from 2.25 to $22.00 \mathrm{mg} / \mathrm{l}$. The result of physical chemical analysis of water samples of Tonk city indicated that tap water of Jawahar Bazar Area (S1), Taj colony Area (S2) and hand pump of Mehandi Bagh Area (S4) were suitable for drinking purpose but hand pump water of Takhata Area (S3) and Civil line Area (S5) were unsuitable for drinking purpose on the basis of calcium and iron concentration. This study thus concludes that hand pump water in study area is chemically unsuitable for drinking and it is recommended to carry out a proper water quality program in study area.

Copy Right, IJAR, 2018,. All rights reserved. 


\section{Introduction:-}

Water is the most abundant and wonderful component of environment for existence of life. It has many unique properties like high specific heat, dielectric constant and universal solvent but now a day the modern civilization, industrialization, human activities and increasing in population have lead to fast degradation of our ground water quality and quantity. Many researchers gave emphasis on drinking water quality parameters and adverse effect on human health. The physical and chemical quality of water are very important like Fluoride occurs naturally in ground water and help in protection against dental caries in children but Fluoride less than $0.5 \mathrm{mg} / \mathrm{l}$ in water lead to tooth decay and more than $1.5 \mathrm{mg} / \mathrm{l}$ causes dental fluorosis (Thivyacet et.al.2015). Nitrate concentration more than $45 \mathrm{mg} / \mathrm{l}$ may cause methemoglobinemia diseases or blue bodies in bottle fed babies (Jain C.K.et.al.2010). High concentration of iron more than $0.3 \mathrm{mg} / \mathrm{l}$ in natural water resources may lead to numerous serious health problems like diabetes, cancer, heart and liver diseases as well as neurodegenerative diseases (Azizullah et. al.2011).

High concentration of calcium and fluoride were reported in drinking water of Bikaner city of Rajasthan (Ajay singh solanki 2013). The ground water quality was evaluated with special reference to fluoride and nitrate concentration in bassi tehsil of jaipur (Umesh S. and Swati S. 2014). In jaipur, ajmer, churu, alwar, jodhpur, pali, bharatpur, jhunjhunu, sikar and karoli low drinking water quality have been reported (Saurabh shashank et. al. 2014). The objectives of this study were to determine the physical and chemical parameters of the ground water of Tonk city and established the pollution load in study area.

\section{Study area:-}

Tonk district with geographical area of 7194 square kilo meter form north-eastern part of the Rajasthan. Tonk district have seven sub division and seven tehsil Tonk, Peeplu, Todaraisingh, Deoli, Niwai, Malpura and Uniyara. It is about 100 kilo meter by road from Jaipur near the right bank of Banas River (GWB 2013). The water works department of Tonk city supplied the drinking water to home by pipe system. The supply of drinking water in city is insufficient due to lack of storage tank in water works department and increasing population year to year. Thus people of Tonk city face the problem of water in summer season. Therefore, people of Tonk city used the tube well water, bore well water and hand pump water for drinking and other purpose during summer season. This water is polluted by various industries effluent and human activity which is dangerous and harmful for health. Thus, to determine the drinking water pollution in Tonk city, five water samples (table -1) were collected from various region of Tonk city. Location of sampling sites illustrated in figure -1 .

Table1:-Sampling sites of Tonk city, Rajasthan, India.

\begin{tabular}{|c|l|l|c|}
\hline $\begin{array}{l}\text { Serial } \\
\text { No. }\end{array}$ & \multicolumn{1}{|c|}{ Source of water sample } & \multicolumn{1}{c|}{$\begin{array}{c}\text { Sampling site Tonk } \\
\text { city }\end{array}$} & Sample Code \\
\hline 1 & Tap Water & Jawahar Bazar Area & S1 \\
\hline 2 & Tap Water & Taj Colony Area & S2 \\
\hline 3 & Hand pump Water & Takhta Area & S3 \\
\hline 4 & Hand pump Water & Mehandi Bagh Area & S4 \\
\hline 5 & Hand pump Water & Civil Line Area & S5 \\
\hline
\end{tabular}




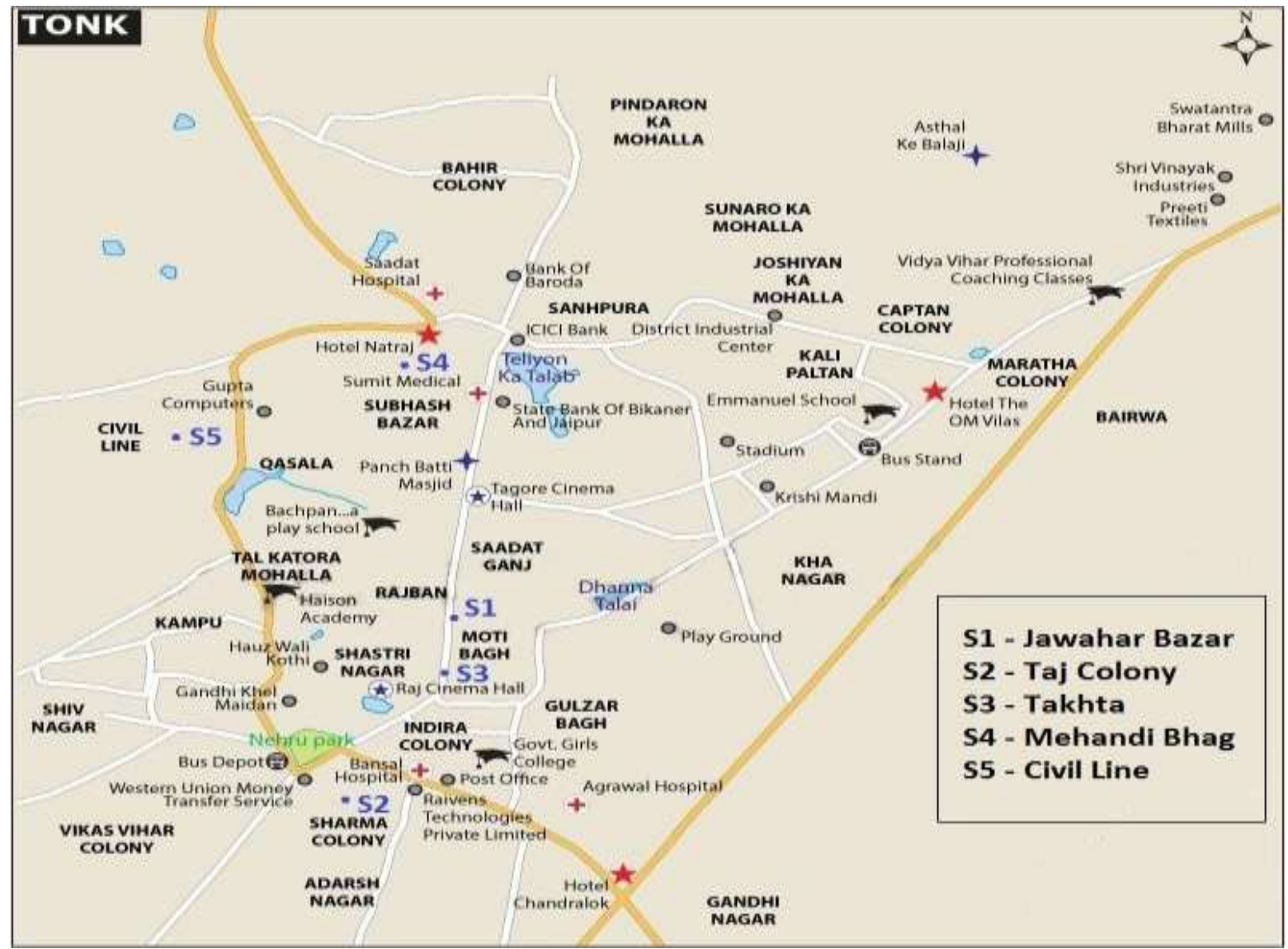

Figure- 1:- Map of Study area with 5 sampling sites

\section{Material and methods:-}

Water Sampling:-

To analyze the physical chemical quality, tap water and hand pump water of 5 sampling sites of Tonk city were collected in pre-cleaned and rinsed polythene bottles with precaution. The sampling was done in morning and afternoon hours from February 2015 to January 2017.

\section{Physical-chemical Analysis of water samples:-}

Fluoride, Iron, Calcium, Magnesium, Sulphate and Nitrate were analysed in each sample of tap and hand pump water. The analysis of water samples were done in accordance with methods of sampling and test (physical and chemical) for water and wastewater, bureau of Indian standard BIS.Fluoride determined by zirconium alizarin method and iron by thiocyanate method. Calcium determined by EDTA titration method. Magnesium and sulphate determined by gravimetric method. Nitrate determined by phenol disulphonic acid method.

\section{Results and discussion:-}

The physical chemical parameters of tap water and hand pump water of Tonk city summarized in table-2.The observed water quality data were compared with desirable and permissible limit of bureau of Indian standard BIS (10500:2012 table-3). Statistical data of water samples depicted in table-4

\section{Fluoride:-}

Dental fluorosis is observed when fluorides exceed the level of $1.5 \mathrm{mg} / \mathrm{l}$ in drinking water. Fluoride concentration in the water samples ranged from 0.0 to $0.3 \mathrm{mg} / \mathrm{l}$. The minimum fluoride values were observed for sample water of sampling sites S1and S2. The maximum fluoride value was observed for sample water of sampling site S3.The fluoride concentration in all sampling sites S1, S2, S3, S4 and S5 were below the desirable limit prescribed by BIS. The graphical representation of fluoride in water samples of Tonk city is depicted in figure-2. 


\section{Iron:-}

Lake of iron in human body causes anemia disease. Iron concentration in water samples varied from 0.1 to 22.22 $\mathrm{mg} / \mathrm{l}$. The minimum iron value was observed in sample water of sampling site S4.The maximum iron value was observed in sample water of sampling site S5. The iron concentration in sampling sites S1, S2 and S4 were observed below desirable limit of BIS. Iron concentration in sampling site S3 and S5 were observed above desirable limit of BIS. The graphical representation of iron concentration in water samples of Tonk city is depicted in figure-3.

\section{Calcium:-}

Calcium is non toxic and may not produce any hazardous effect on human health. Calcium concentration in water samples varied from 45.29 to $252.50 \mathrm{mg} / \mathrm{l}$. The minimum calcium value was observed in sample water of sampling site $\mathrm{S} 1$. The maximum calcium value was observed in sample water of sampling siteS3.The calcium concentration in sampling sites S1, S2 and S5 were observed below desirable limit of BIS. Calcium concentration in sampling site S4 was observed above desirable limit of BIS. Calcium concentration in sampling sites S3 was observed above permissible limit of BIS. The graphical representation of calcium concentration in water samples of Tonk city is depicted in figure-4.

\section{Magnesium:-}

Magnesium concentration in water samples varied from 6.65 to $37.84 \mathrm{mg} / \mathrm{l}$. The minimum magnesium value was observed in sample water of sampling site S5.The maximum magnesium value was observed in sample water of sampling site S3. The magnesium concentration in sampling sites S1, S2, S4 and S5 were observed below desirable limit of BIS. Magnesium concentration in sampling site S3 was observed above desirable limit. The graphical representation of magnesium concentration in water samples of Tonk city is depicted in figure-5.

\section{Sulphate:-}

Sulphate concentration higher than $800 \mathrm{mg} / \mathrm{l}$ in drinking water causes cathartic effect Sulphate concentration in water samples varied from 25.74 to $94.65 \mathrm{mg} / \mathrm{l}$. The minimum sulphate value was observed in sample water of sampling site S1. The maximum sulphate value was observed in sample water of sampling siteS3. Sulphate concentration in sampling sites S1, S2, S3, S4 and S5 were observed below desirable limit of BIS. The graphical representation sulphate concentration in water samples of Tonk city is depicted in figure-6.

\section{Nitrate:-}

High concentration of nitrate in drinking water give bad effect to bottle fed babies. Nitrate concentration in water samples varied from 2.25 to $22.00 \mathrm{mg} / \mathrm{l}$. The minimum nitrate value was observed in sample water of sampling site S4.The maximum nitrate value was observed in sample water of sampling site S2. Nitrate concentration in sampling sites S1, S2, S3, S4 and S5 were observed below desirable limit of BIS. The graphical representation of nitrate concentration in water samples of Tonk city is depicted in figure-7.

Table-2:- Observed water quality data of Tonk city, Rajasthan, India

\begin{tabular}{|c|l|l|l|l|l|l|l|}
\hline S.N. & Parameters & Unit & \multicolumn{5}{|c|}{ Sampling Sites } \\
\cline { 4 - 8 } & & & $\mathrm{S} 1$ & $\mathrm{~S} 2$ & $\mathrm{~S} 3$ & S4 & S5 \\
\hline 1. & Fluoride & $\mathrm{mg} / \mathrm{l}$ & 0.0 & 0.0 & 0.3 & 0.1 & 0.1 \\
\hline 2. & Iron & $\mathrm{mg} / \mathrm{l}$ & 0.20 & 0.25 & 0.72 & 0.1 & 22.22 \\
\hline 3. & Calcium & $\mathrm{mg} / \mathrm{l}$ & 45.29 & 46.68 & 252.50 & 77.43 & 47.13 \\
\hline 4. & Magnesium & $\mathrm{mg} / \mathrm{l}$ & 10.56 & 11.79 & 37.84 & 11.25 & 6.65 \\
\hline 5. & Sulphate & $\mathrm{mg} / 1$ & 25.74 & 26.33 & 94.65 & 39.09 & 27.38 \\
\hline 6. & Nitrate & $\mathrm{mg} / 1$ & 21.00 & 22.00 & 6.75 & 2.25 & 2.81 \\
\hline
\end{tabular}

Table-3:- BIS standard of drinking water

\begin{tabular}{|c|c|l|l|l|}
\hline Serial No. & Parameters & Desirable limit & Permissible Limit & Unit \\
\hline 1. & Fluoride & 1.0 & 1.5 & $\mathrm{mg} / \mathrm{l}$ \\
\hline 2. & Iron & 0.3 & No relaxation & $\mathrm{mg} / \mathrm{l}$ \\
\hline 3. & Calcium & 75 & 200 & $\mathrm{mg} / \mathrm{l}$ \\
\hline 4. & Magnesium & 30 & 100 & $\mathrm{mg} / \mathrm{l}$ \\
\hline 5. & Sulphate & 200 & 400 & $\mathrm{mg} / \mathrm{l}$ \\
\hline 6. & Nitrate & 45 & No relaxation & $\mathrm{mg} / \mathrm{l}$ \\
\hline
\end{tabular}


Table-4:- Statistical data of sample water of Tonk city, Rajasthan, India.

\begin{tabular}{|c|l|l|l|l|l|}
\hline S.N. & Parameters & Unit & Minimum & Maximum & Average \\
\hline 1. & Fluoride & $\mathrm{mg} / \mathrm{l}$ & 0 & 0.3 & 0.1 \\
\hline $\mathbf{2 .}$ & Iron & $\mathrm{mg} / \mathrm{l}$ & 0.1 & 22.22 & 4.69 \\
\hline $\mathbf{3 .}$ & Calcium & $\mathrm{mg} / \mathrm{l}$ & 45.29 & 252.50 & 93.92 \\
\hline $\mathbf{4 .}$ & Magnesium & $\mathrm{mg} / \mathrm{l}$ & 6.65 & 37.84 & 15.61 \\
\hline $\mathbf{5 .}$ & Sulphate & $\mathrm{mg} / \mathrm{l}$ & 25.74 & 94.65 & 42.63 \\
\hline 6. & Nitrate & $\mathrm{mg} / \mathrm{l}$ & 2.25 & 22.00 & 10.96 \\
\hline
\end{tabular}

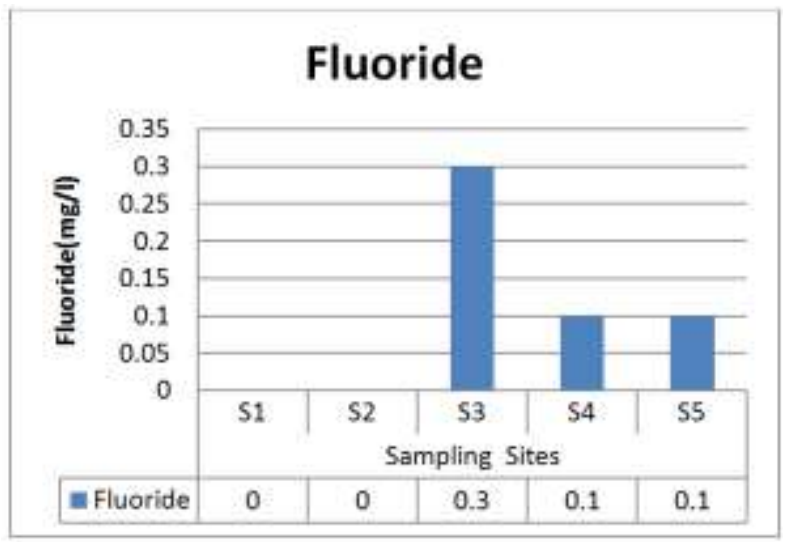

Figure 2:-Variation in Fluoride with sampling sites of Tonk City

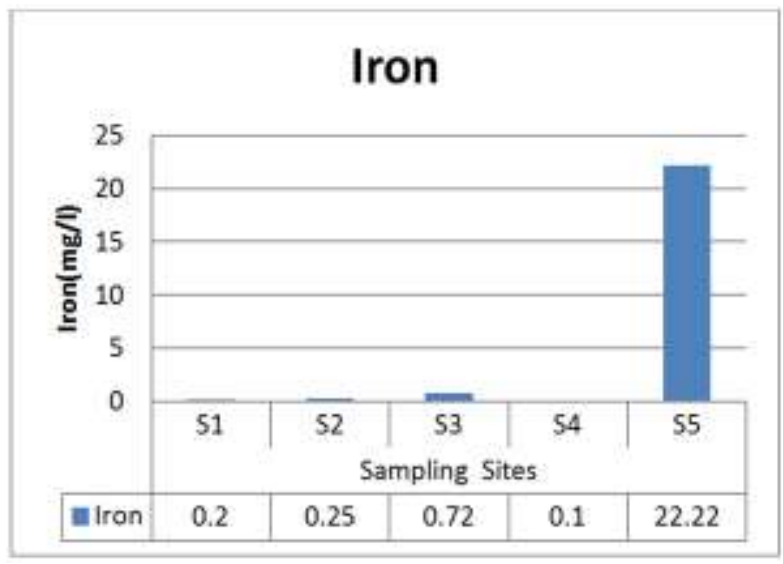

Figure 3:- Variation in Iron with sampling sites of Tonk City

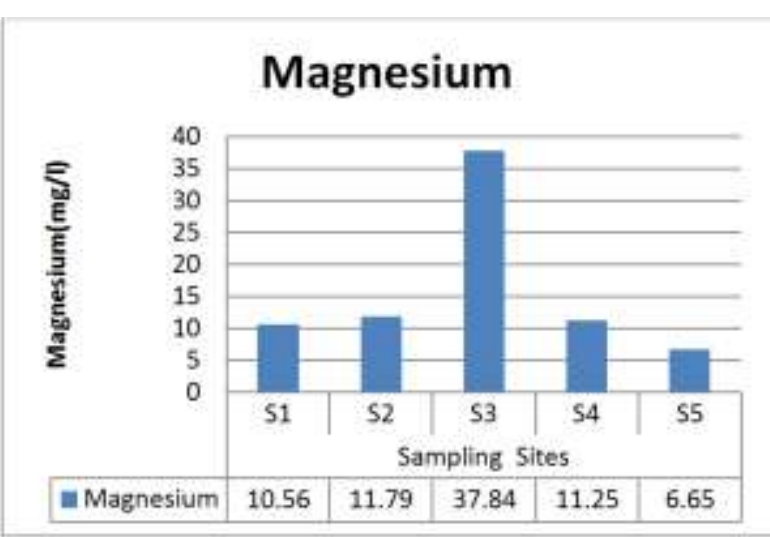

Figure 5:-Variation in Magnesium with sampling sites of TonkCity

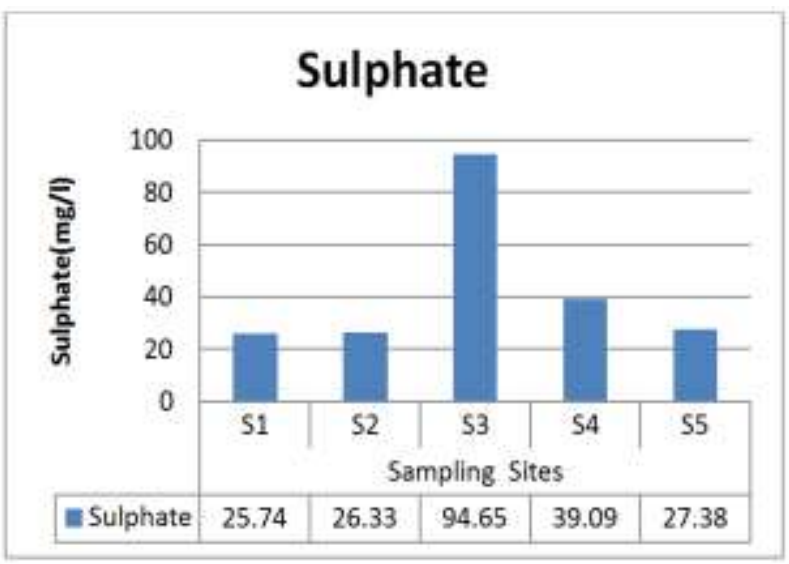

Figure 6:- Variation in Sulphate with sampling sites of Tonk City 


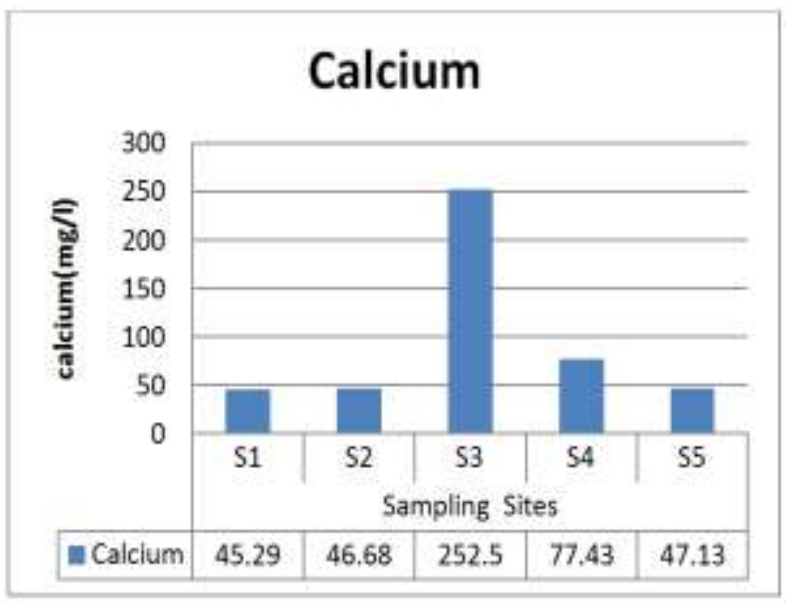

Figure4:-Variation in Calcium with sampling sites of Tonk City

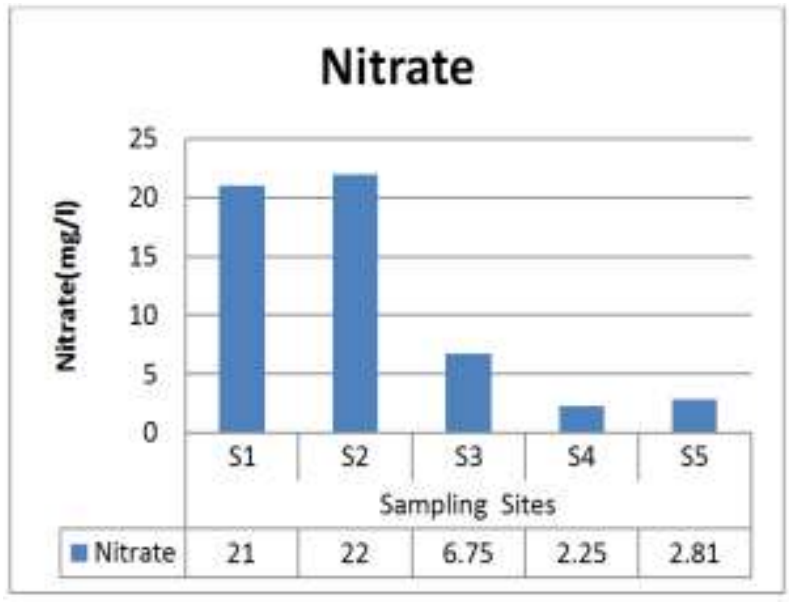

Figure 7:- Variation in Nitrate with sampling sites of Tonk city

\section{Conclusion:-}

The physical chemical analysis of water samples collected from different sites of Tonk city concluded that water samples of Jawahar Bazaar Area (S1), Taj Colony Area (S2) and Mehandi Bagh Area (S4) were found to be suitable for drinking purpose but hand pump water samples of Takhata Area (S3) and civil line tonk (S5) were found to be not suitable for drinking purpose on the basis of calcium and iron concentration limit of bureau of Indian standard (BIS10500.2012). Such hand pump water requires proper treatment for calcium and iron concentration before used by peoples of study area.

\section{References:-}

1. Azizullah A,Khan Ckhattak M N , Richter P (2011).water pollution in Pakistan and its impact on public health a review Environment 37:479-49

2. BIS(1987) method of sampling and test (physical and chemical) bureau of Indian standard, Manak Bhawan, New Delhi.

3. BIS (1991)10500:2012 drinking water quality parameters, bureau of Indian standard, Manak Bhawan, New Delhi.

4. CGWB (2013),ground water information Tonk district Rajasthan, western region Tonk.pp-1-4

5. Jain C K. Bandyopadhyay A,Bhadra A(2010). Assessment of ground water quality for drinking purpose, district Nainital, Uttarakhand, India. Environment monitoring assessment 166:663-676.

6. Saxena U. and Saxena S.(2014).ground water quality evaluation with special reference to fluoride and nitrate contamination in Bassi Tehsil District Jaipur, Rajasthan India. International journal of environment sciences.vol5 no.1

7. Shashank S, Singh D, Tiwaris (2014).Drinking water quality of Rajasthan Districts. Journal of basic and applied engineering research. Vol.1, no 10 pp105-109.

8. Singh Solanki Ajay (2013), studies of various water quality parameters with reference to human health a case study of Bikaner city of Rajasthan. Rasayan journal vol.6, no. 1, 44-46.

9. Thiuya C.,Chidambaram S,Rao, Thilagavathi R,Prasanna MV,Manikandan S (2015).Assessment of fluoride contamination in ground water of hard rock, aquifes in Madurai, district, Tamilnadu (India). 